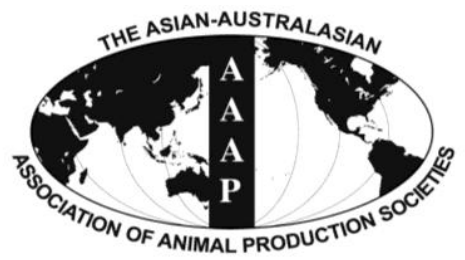

Asian Australas. J. Anim. Sci.

Vol. 26, No. 6 : 827-830 June 2013

http://dx.doi.org/10.5713/ajas.2012.12704

www.ajas.info

pISSN $1011-2367$ elSSN 1976-5517

\title{
Effects of Feeding Levels of Starter on Weaning Age, Performance, Nutrient Digestibility and Health Parameters in Holstein Dairy Calves
}

\author{
J. Ghassemi Nejad, A. Hosseindoust ${ }^{1}$, A. Shoae ${ }^{2}$, B. Ghorbani ${ }^{1}$, B. H. Lee, E. Oskoueian ${ }^{3}$, \\ D. Hajilari ${ }^{1}$, A. Amouzmehr ${ }^{1}$, J. D. Lohakare and K. I. Sung* \\ College of Animal Life Sciences, Kangwon National University, Chuncheon, 200-701, Korea
}

\begin{abstract}
To evaluate the effects of feeding four different levels of starter in male Holstein dairy calves, a completely randomized study was conducted, using 28 calves with initial body weight of $40.5 \pm 2.4 \mathrm{~kg}$. The animals were fed iso-nitrogenous starter and were weaned when they consumed 350,500, 650 and $800 \mathrm{~g} / \mathrm{d}$ of starter for $3 \mathrm{~d}$ consecutively. Starter and water were available ad-libitum throughout the experiment. Body weight at pre-weaning (less than $5 \mathrm{wk}$ ) and post-weaning ( $8 \mathrm{wk}$ ) was lower in calves that received 350 $\mathrm{g} / \mathrm{d}$ of starter than in the other treatments $(\mathrm{p}<0.05)$. Feed conversion ratio (FCR) was the highest among all treatments in pre-weaning period $(\mathrm{p}<0.05)$. Dry matter intake (DMI) at weaning and total DMI was higher in that calves received $800 \mathrm{~g} / \mathrm{d}$ of starter compared with other treatments $(\mathrm{p}<0.05)$. Calves fed 350 and $500 \mathrm{~g} / \mathrm{d}$ of starter were weaned earlier $(\mathrm{p}<0.05)$ and showed lower milk consumption $(\mathrm{kg}$, DM) compared with other treatments whereas no significant difference was observed between calves fed 350 and $500 \mathrm{~g} / \mathrm{d}$ of starter ( $>0.05)$. Dry matter, organic matter and crude protein digestibilities were lower in calves that received $350 \mathrm{~g} / \mathrm{d}$ of starter compared with other treatments $(\mathrm{p}<0.05)$. No differences were observed in acid detergent and neutral detergent fiber digestibility among all treatments ( $p>0.05)$. Treatments had no significant effect on time of starting rumination, respiratory score, and days of drug administration for pneumonia. There were no meaningful differences in feces, fecal odor scores, body temperature, and days of drug administration for diarrhea among all treatments ( $>0.05$ ). Total dry matter intake at the end of experiment showed no significant difference among calves fed 600 and $800 \mathrm{~g} / \mathrm{d}$ of starter, but calves fed 350 and $500 \mathrm{~g} / \mathrm{d}$ of starter showed more dry matter (DM) intake than calves in the 600 and 800 g/d groups (p<0.05). (Key Words: Holstein Dairy Calves, Levels of Starter, Health, Performance)
\end{abstract}

\section{INTRODUCTION}

Calves could be weaned after they consume a specific amount of starter in a specific period of time, mostly 2 to 3 d continuously (Morrill et al., 1995; Abdelgadir et al., 1996). Coverdale et al. (2004) started their weaning when all calves were consuming $450 \mathrm{~g}$ of starter on d 52 of the trial. Franklin et al. (2003) started the weaning process when calves had consumed $680 \mathrm{~g}$ of starter/d for $2 \mathrm{~d}$, consecutively. Appleman and Owen (1975) reported that the

\footnotetext{
* Corresponding Author: KyungIl Sung. Tel: +82-33-250-8635, Fax: +82-33-242-4540, E-mail: kisung@ @angwon.ac.kr

1 Department of Animal Science, Gorgan University of Agricultural Sciences \& Natural Resources, Iran.

2 Department of Zoology, University of Otago, 340 Great King Street, Dunedin 9016, New Zealand.

3 Department of Microbiology, Faculty of Biotechnology and Biomolecular Sciences, University Putra Malaysia, 43400, Serdang, Selangor, Malaysia.

Submitted Dec. 19, 2012; Accepted Feb. 24, 2013; Revised Mar. 15, 2013
}

predetermined dry feed intake (DFI) used to set up the weaning of dairy calves ranged from 454 to $908 \mathrm{~g} / \mathrm{d}$. Leaver and Yarrow (1972) weaned calves at three different dry feed intake ranges (DFIR). Those researchers inferred that a DFIR of $400 \mathrm{~g} / \mathrm{d}$ for 3 consecutive $d$ was adequate for calves and decreased days to weaning compared to a DFIR of 650 and $900 \mathrm{~g} / \mathrm{d}$ for 3 consecutive $\mathrm{d}$.

Time of weaning is a critical point in dairy calf breeding. Weaning at different times can affect performance and health parameters directly. Greenwood et al. (1997) reported that calves in the $1 \%$ treatment group (dry feed intake as a percentage of birth weight as a weaning criterion) met the weaning criterion earlier than did those in the $1.5 \%$ and $2 \%$ treatment groups. Limited consumption of milk is very useful for calf rearing management and decreases weaning age as it encourages calves to consume more starter before weaning (Davis and Drackley, 1998). Any decrease in weaning age could improve calves' health, lessen diarrhea and consequently improves performance. Therefore, the aim of this study was to determine the effect 
of feeding levels of starter on weaning age, performance, digestibility and health parameters in dairy calves receiving ad libitum starter.

\section{MATERIALS AND METHODS}

Twenty eight male Holstein dairy calves born between Feb and Apr 2010 were allocated to four treatments from birth to $\mathrm{d}$ 56. Treatments included: weaning after consuming starter at $350,500,650$, and $800 \mathrm{~g} / \mathrm{d}$ for $3 \mathrm{~d}$ consecutively. Calves were weighed and assigned to treatments after $3 \mathrm{~d}$ of birth and the ration used in this trial was according to NRC requirements for dairy animals (2001). Milk was provided in 2 equal feedings at $8 \%$ of birth weight per day prior to weaning and/or the first $3 \mathrm{~d}$, calves received the same percent of colostrum as well. Calves were housed in individual hutches $(1.5 \times 2.5 \mathrm{~m}$ individual pens) bedded with straw. Water was offered $a d$ libitum after $3 \mathrm{~d}$ when calves were assigned to the treatments. Starter was formulated to be iso-nitrogenous at $19.5 \% \mathrm{CP}$ and $90.5 \% \mathrm{DM}$ in the form of pellets. The ingredients and composition of the starter are provided in Table 1.

Starter intake was monitored daily, and body weights were obtained at the time of weaning and at d 56. Amounts of starter and milk consumption offered and refused were recorded daily. Fecal scores were subjectively scored once

Table 1. Experimental diet constituents and calculated composition of starter

\begin{tabular}{lc}
\hline Nutrients & \% of DM \\
\hline Dry matter & 90.5 \\
Crude protein & 19.5 \\
Acid detergent fiber & 5.8 \\
Neutral detergent fiber & 13.1 \\
Calcium & 1.2 \\
Phosphorous & 0.7 \\
Organic matter & 89.3 \\
Metabolizable energy (Mcal/kg) & 2.3 \\
Ingredients & Percent $(\%)$ \\
Corn & 22.5 \\
Barley & 26.5 \\
Soybean meal & 20 \\
Cotton seed meal & 9 \\
Canola meal & 5.3 \\
Fish meal & 1.7 \\
Molasses & 4 \\
Wheat bran & 7.2 \\
Sodium bicarbonate & 0.5 \\
Calcium carbonate & 1.35 \\
Calcium phosphate & 0.35 \\
Magnesium oxide & 0.2 \\
Mineral-vitamin premix & 1 \\
Salt & 0.4 \\
\hline
\end{tabular}

daily using a scale of $1=$ normal feces, $2=$ soft to loose, $3=$ loose to watery, 4 = watery, mucous, slightly bloody, and 5 = watery, mucous, bloody. Respiratory scoring was done once daily using a scale of $1=$ normal, $2=$ slight cough, $3=$ moderate cough, $4=$ moderate to severe cough, and $5=$ severe and chronic cough. Also, fecal odor scoring was measured on the scale: $1=$ normal, $2=$ slightly offensive and 3 = highly offensive. Body temperature (using rectal thermometer) was recorded every week (Larson et al., 1977). All calves were monitored every day for the time of starting rumination. Feed and fecal samples were collected for $5 \mathrm{~d}$ after weaning (wk 8) for evaluating nutrient digestibility (AOAC, 1990). Feed residues were collected and weighed every day at $8 \mathrm{AM}$ in the morning for each calf separately for $5 \mathrm{~d}$. All feces were collected and weighed at 8:30 AM for each calf separately from individual hutches during these $5 \mathrm{~d}$ at the end of the experiment. Then all feed and feces for each calf were mixed together, a sample taken and stored $\left(-20^{\circ} \mathrm{C}\right)$ for further analysis.

Data was analyzed using the linear model (PROC GLM) of SAS (1996). Differences were observed at $p<0.05$ and Duncan comparisons used for means evaluations. Data in the tables collected at weaning and the final data reported at d 56 (wk 8). Initial body weight as a covariate was included in the model when appropriate but was removed from the model when not significant.

\section{RESULTS AND DISCUSSION}

\section{Effects of treatments on body weight, dry matter intake and feed conversion}

Body weights (BW) were recorded at the beginning, weaning time and the end of trial for all calves. In the pre weaning period, the differences of $\mathrm{BW}$ between treatments were significant $(\mathrm{p}<0.05)$. The higher body weight found in calves receiving 600 and $800 \mathrm{~g} / \mathrm{d}$ of starter compared with calves receiving $350 \mathrm{~g} / \mathrm{d}$ of starter might be explained by the higher dry matter intake (DMI) in these two treatments (Table 3). Difference in BW between calves receiving 350 and $500 \mathrm{~g} / \mathrm{d}$ of starter was not significant (Table 2). Therefore, DMI in these two treatments was not different ( $p>0.05)$. This result is in agreement with the studies of Coverdale et al. (2004), Franklin et al. (2003), and Greenwood et al. (1997) who reported no significant difference in BW until wk 5. However, reduced BW gain after weaning has been reported by some researchers (Huber et al., 1984; Anderson et al., 1987; Luchini et al., 1991). Starter intake and growth rate in the post-weaning period were $5.8 \mathrm{~kg}$ and $0.45 \mathrm{~kg} / \mathrm{d}, 4.1 \mathrm{~kg}$ and $0.65 \mathrm{~kg} / \mathrm{d}, 4.2$ $\mathrm{kg}$ and $0.77 \mathrm{~kg} / \mathrm{d}, 3.4 \mathrm{~kg}$ and $0.75 \mathrm{~kg} / \mathrm{d}$ for calves in $350 \mathrm{~g} / \mathrm{d}$, $500 \mathrm{~g} / \mathrm{d}, 650 \mathrm{~g} / \mathrm{d}$, and $800 \mathrm{~g} / \mathrm{d}$ groups, respectively. No differences were observed in $\mathrm{BW}$ at the end of trial between calves receiving 500, 650 and $850 \mathrm{~g} / \mathrm{d}$ of starter and in FCR 
Table 2. Effects of levels of starter on body weight and feed conversion

\begin{tabular}{|c|c|c|c|c|c|c|}
\hline \multirow{2}{*}{ Period } & \multirow{2}{*}{ Traits } & \multicolumn{4}{|c|}{ Level of starter* $(\mathrm{g} / \mathrm{d})$} & \multirow{2}{*}{ SE } \\
\hline & & 350 & 500 & 650 & 800 & \\
\hline \multirow[t]{2}{*}{ Pre weaning } & Body weight (kg) & $44.0^{\mathrm{a}}$ & $46.8^{\mathbf{a b}}$ & $50.9^{\mathbf{b}}$ & $53.2^{\mathbf{b}}$ & 1.82 \\
\hline & Feed conversion & $3.4^{\mathrm{b}}$ & $2.9^{\mathrm{a}}$ & $2.6^{\mathrm{a}}$ & $2.2^{\mathrm{a}}$ & 0.36 \\
\hline \multirow[t]{2}{*}{ Post weaning (Week 8) } & Body weight (kg) & $58.2^{\mathbf{b}}$ & $64.4^{\mathrm{a}}$ & $68.3^{\mathrm{a}}$ & $67.9^{\mathrm{a}}$ & 2.17 \\
\hline & Feed conversion & 2.6 & 2.7 & 3.2 & 2.6 & 0.47 \\
\hline
\end{tabular}

${ }^{\mathrm{ab}}$ Means within the same row without a common superscript differ at $(\mathrm{p}<0.05)$.

* Level of starter including 350, 500, 650, and $800 \mathrm{~g} / \mathrm{d}$.

Table 3. Effects of levels of starter on total DMI (milk and starter), days to weaning and time of starting rumination

\begin{tabular}{llllll}
\hline \multirow{2}{*}{ Explain } & \multicolumn{4}{c}{ Level of starter $(\mathrm{g} / \mathrm{d})$} & \multirow{2}{*}{ SE } \\
\cline { 2 - 5 } & 350 & 500 & 650 & 800 & \\
\hline DMI at weaning (kg) & $13.3^{\mathbf{a}}$ & $16^{\mathbf{a b}}$ & $20.1^{\mathbf{c}}$ & $24.2^{\mathbf{d}}$ & \\
Total DMI (kg) & $34.3^{\mathbf{a}}$ & $39.6^{\mathbf{b}}$ & $45.2^{\mathbf{c}}$ & $51.1^{\mathbf{d}}$ & \\
Week 8 & & & & & \\
$\quad$ Weaning age (d) & $25.3^{\mathbf{a}}$ & $30^{\mathbf{a b}}$ & $34.2^{\mathbf{b}}$ & $35.6^{\mathbf{b c}}$ & 2.17 \\
$\quad$ Milk consumption (DM, kg) & $10.4^{\mathbf{a}}$ & $11.8^{\mathbf{a b}}$ & $13.7^{\mathbf{b}}$ & $14.3^{\mathbf{b c}}$ & 1.50 \\
$\quad$ Time of starting rumination (d) & 26.3 & 23.6 & 22.6 & 25 & 2.57 \\
\hline
\end{tabular}

${ }^{\mathrm{abc}}$ Means within the same row without a common superscript differ at $(\mathrm{p}<0.05)$

for all treatments as well. Only BW in calves fed $350 \mathrm{~g} / \mathrm{d}$ of starter at the end of the trail was the lower and was related to their lower BW at weaning age. A poorer feed conversion ratio $(\mathrm{p}<0.05)$ in calves receiving $350 \mathrm{~g} / \mathrm{d}$ of starter might be explained by a low DMI (Table 3) and a poorer health condition (Table 5). Coverdale et al. (2004) found no difference in body weight gain, average daily gain, and feed efficiency, in calves fed with ground starter compared to those fed a commercial coarse starter prior to weaning (consuming $450 \mathrm{~g} / \mathrm{d}$ of starter). Average daily gains of male calves from birth to $30 \mathrm{~d}, 30$ to $60 \mathrm{~d}$, and 60 to $90 \mathrm{~d}$ were $0.38 \pm 0.03,0.93 \pm 0.03$ and $1.01 \pm 0.04$, respectively (Arrayet et al., 2002).

DMI at weaning age in calves receiving $350 \mathrm{~g} / \mathrm{d}$ of starter differed $(\mathrm{p}<0.05)$ in comparison with calves receiving 600 and $800 \mathrm{~g} / \mathrm{d}$ of starter, but no difference ( $>>0.05$ ) was observed in DMI between calves receiving 350 and $500 \mathrm{~g} / \mathrm{d}$ of starter (Table 3). This may be due to the time taken to achieve weaning age in calves receiving 350 and $500 \mathrm{~g} / \mathrm{d}$ of starter. But, it is clear that weaning age in calves receiving $350 \mathrm{~g} / \mathrm{d}$ of starter was the youngest among all treatments $(\mathrm{p}<0.05)$. Calves that weaned earlier had less time to consume starter and milk before weaning compared with the others. Lower DMI and BW in calves receiving $350 \mathrm{~g} / \mathrm{d}$ of starter also might be explained by lower dry matter, organic matter and crude protein digestibility in this treatment (Table 4). Consequently, more nutrients were available to calves receiving 500 or more g/d of starter $(500$, 650 , and $800 \mathrm{~g} / \mathrm{d}$ ). Hence, these calves gained more BW than calves receiving $350 \mathrm{~g} / \mathrm{d}$ of starter. Greenwood et al. (1997) reported the same result in regards to reducing weaning age by decreasing starter intake to $1 \%$ of initial body weight. Franklin et al. (2003) reported calves fed textured starter consumed more total grain, were weaned earlier, and weighed more at 6 wk of age than calves fed pelleted starter. Coverdale et al. (2004) found no difference in weaning age with respect to their treatments. Milk consumption $(\mathrm{kg}, \mathrm{DM})$ was lower in calves receiving 350 $\mathrm{g} / \mathrm{kg}$ of starter than other treatments $(\mathrm{p}<0.05)$. Lower milk consumption in calves receiving $350 \mathrm{~g} / \mathrm{kg}$ of starter might be explained by lower weaning age compare to other treatments (Table 3). No significant difference was observed between calves receiving 350 and $500 \mathrm{~g} / \mathrm{d}$ of starter in milk consumption ( $p>0.05$ ). No differences were observed in the time of starting rumination $(p>0.05)$.

\section{Effects of treatments on nutrients digestibility of feed and health parameters}

Dry matter (DM), organic matter, $(\mathrm{OM})$, crude protein (CP), acid detergent fiber (ADF) and neutral detergent fiber (NDF) digestibility are shown in Table 4. DM, OM and CP digestibility in calves that received $350 \mathrm{~g} / \mathrm{d}$ of starter was lower than the other treatments $(\mathrm{p}<0.05)$ but no differences

Table 4. Effects of levels of starter on nutrients digestibility of feed

\begin{tabular}{|c|c|c|c|c|c|}
\hline \multirow{2}{*}{$\begin{array}{l}\text { Nutrients } \\
(\%)\end{array}$} & \multicolumn{4}{|c|}{ Level of starter $(\mathrm{g} / \mathrm{d})$} & \multirow{2}{*}{ SE } \\
\hline & 350 & 500 & 650 & 800 & \\
\hline$\overline{\mathrm{DM}}$ & $68.4^{\mathrm{b}}$ & $79.0^{\mathrm{a}}$ & $75.3^{\mathrm{a}}$ & $76.5^{\mathrm{a}}$ & 2.82 \\
\hline $\mathrm{OM}$ & $70.4^{\mathrm{b}}$ & $80.6^{\mathrm{a}}$ & $81.0^{\mathrm{a}}$ & $78.9^{\mathrm{a}}$ & 1.92 \\
\hline $\mathrm{CP}$ & $57.6^{\mathrm{b}}$ & $65.7^{\mathrm{a}}$ & $66.8^{\mathrm{a}}$ & $65.6^{\mathrm{a}}$ & 1.21 \\
\hline $\mathrm{ADF}$ & $34.6^{\mathrm{a}}$ & $37.1^{\mathrm{a}}$ & $34.4^{\mathrm{a}}$ & $35.6^{\mathrm{a}}$ & 2.27 \\
\hline $\mathrm{NDF}$ & $39.0^{\mathrm{a}}$ & $36.9^{\mathrm{a}}$ & $37.6^{\mathrm{a}}$ & $38.7^{\mathrm{a}}$ & 2.03 \\
\hline
\end{tabular}

ab Means within the same row without a common superscript differ at $(\mathrm{p}<0.05)$. 
Table 5. Effects of levels of starter on health parameters

\begin{tabular}{lccccc}
\hline \multirow{2}{*}{ Explain } & \multicolumn{2}{c}{ Level of starter $(\mathrm{g} / \mathrm{d})$} & \multicolumn{2}{c}{ SE } \\
\cline { 2 - 5 } & 350 & 500 & 650 & 800 & 0.65 \\
Fecal score & $3^{\mathbf{b}}$ & $1.3^{\mathbf{a}}$ & $1.3^{\mathbf{a}}$ & $1.5^{\mathbf{a}}$ & \\
Respiratory score & 1.3 & 1.2 & 1 & 1.2 & 0.23 \\
Odor score & $2^{\mathbf{b}}$ & $1.3^{\mathbf{a}}$ & $1.3^{\mathbf{a}}$ & $1.2^{\mathbf{a}}$ & 0.18 \\
Body temperature & $39.4^{\mathbf{b}}$ & $38.9^{\mathbf{a}}$ & $38.9^{\mathbf{a}}$ & $38.7^{\mathbf{a}}$ & 0.11 \\
Days of drug administration for diarrhea & $5^{\mathbf{b}}$ & $2.5^{\mathbf{a}}$ & $2.5^{\mathbf{a}}$ & $1.5^{\mathbf{a}}$ & 1.82 \\
Days of drug administration for pneumonia & 2 & 2 & 1 & 1 & 0.06 \\
\hline
\end{tabular}

${ }^{\mathrm{ab}}$ Means within the same row without a common superscript differ at $(\mathrm{p}<0.05)$.

were observed between calves receiving 500, 650, and 800 $\mathrm{g} / \mathrm{d}$ of starter ( $\mathrm{p}>0.05$ ). Lower DM, OM and CP digestibility of starter could be due to the younger weaning age resulting in a lower level of starter intake in calves fed $350 \mathrm{~g} / \mathrm{d}$ of starter. The calves' rumens were not sufficiently developed when weaned as early as $25 \mathrm{~d}$ of age. No differences $(p>0.05)$ were observed in ADF and NDF digestibility among all treatments $(\mathrm{p}>0.05)$.

Feces, respiration, and fecal odor were scored as health parameters. Body temperature, days of drug administration for diarrhea and pneumonia were also noted to determine if treatments had an effect on calves' health (Table 5). Coverdale et al. (2004) reported that daily scores, electrolyte and antibiotic administration did not differ by treatments $(p>0.05)$. The greatest incidence of fecal scores more than 2 occurred during wk 2 and 3 which is consistent with previous reports (Quigley et al., 1995; Franklin et al., 2003). Days of drug administration for diarrhea in calves receiving $350 \mathrm{~g} / \mathrm{d}$ of starter was greater $(\mathrm{p}<0.05)$ than the other treatments. It can be illustrated by the earlier weaning age at $350 \mathrm{~g} / \mathrm{d}$ and decreasing starter intake after weaning. Regarding to diarrhea, the fecal odor score of calves fed $350 \mathrm{~g} / \mathrm{d}$ of starter increased and continued for $3 \mathrm{~d}$ even after drug administration. Following diarrhea, calves manure tended to be watery with mucus and their body temperature tended to decrease. There were no differences $(p>0.05)$ between treatments in days of drug administration for pneumonia (Table 5).

We conclude that when calves are weaned only after consuming $500 \mathrm{~g} / \mathrm{d}$ or more of starter their performance, nutrient digestibility and general health conditions are improved and their weaning age decreased. Therefore, the best time for weaning is when calves are consuming starter at $500 \mathrm{~g} / \mathrm{d}$ (more than 1 percent of initial body weight) for 3 d consecutively.

\section{REFERENCES}

Abdelgadir, I. E. O., J. L. Morrill and J. J. Higgins. 1996. Effect of roasted soybeans and corn on performance and ruminal and blood metabolites of dairy calves. J. Dairy Sci. 79:465-474.

Anderson, K. L., T. G. Nagaraja and J. L. Morrill. 1987. Ruminal metabolic development in calves weaned conventionally or early. J. Dairy Sci. 70:1000-1005.

Appleman, R. D. and F. G. Owen. 1975. Breeding, housing, and feeding management. J. Dairy Sci. 58:447-464.

Arrayet, J. L., A. M. Oberbauer, T. R. Famula, I. Garnett, J. W. Oltjen, J. Imhoof, M. E. Kehrli, Jr. and T. W. Graham. 2002. Growth of Holstein calves from birth to 90 days: The influence of dietary zinc and BLAD status. J. Anim. Sci. 80:545-552.

Association of Official Analytical Chemists (AOAC). 1990. 13th edition. Pubic. By AOAC, P.O.B. Box 54, Washington, DC, USA.

Coverdale, J. A., H. D. Tyler, J. D. Quigley and J. A. Brumm. 2004. Effect of various levels of forage and form of diet on rumen development and growth in calves. J. Dairy Sci. 87:2554-2562.

Davis, C. L. and J. K. Drackley. 1998. Development, nutrition and management of the young calf. First ed. USA: Iowa state university press.

Franklin, T., D. M. Amaral-Phillips, J. A. Jackson, and A. A. Campbell. 2003. Health and performance of Holstein calves that suckled or were hand-fed colostrum and were fed one of three physical forms of starter. J. Dairy Sci. 86:2145-2153.

Greenwood, R. H., J. L. Morrill and E. C. Titgemeyer. 1997. Using dry feed intake as a percentage of initial body weight as a weaning criterion. J. Dairy Sci. 80:2542-2546.

Huber, J. T., A. G. Silva, O. F. Campos and C. M. Mathieu. 1984. Influence of feeding different amounts of milk on performance, health, and absorption capability of baby calves. J. Dairy Sci. 67:2957-2963

Larson, L. L., F. G. Owen, J. L. Albright, R. D. Appelman, R. C. Lamb and L. D. Muller. 1977. Guidelines toward more uniformity in measuring and reporting calf experimental data. J. Dairy Sci. 60:989-991

Leaver, J. D. and N. H. Yarrow. 1972. Rearing of dairy cattle 2. Weaning calves according to their concentrate intake. Anim. Prod. 14:161-165.

Luchini, N. D., S. F. Lane and D. K. Combs. 1991. Evaluation of starter diet crude protein level and feeding regimen for calves weaned at 26 d of age. J. Dairy Sci. 74:3949-3955.

Morrill, J. L. 1995. The calf: birth to 12 weeks. 1992. "Large Dairy Herd Management". (Ed. H. H. Van Horn and C. J. Wilcox). American Dairy Science Association, Savoy. 401-410.

Quigley, J. D., K. R. Martin, D. A. Bemis, L. N. D. Potgieter, C. R. Reinemeyer, B. W. Rohrbach, H. H. Dowlen and K. C. Lamar. 1995. Effects of housing and colostrums feeding on serum immunoglobulins, growth, and fecal scores of Jersey calves. J. Dairy Sci. 78:893-901.

SAS: 1989-1996, SAS Institute Incorporation, Cary, NC, USA. 